IZA DP No. 9521

Entrepreneurship and the Reallocation of African Farmers

Wim Naudé

November 2015 


\title{
Entrepreneurship and the Reallocation of African Farmers
}

\author{
Wim Naudé \\ Maastricht University, MsM \\ and IZA
}

\section{Discussion Paper No. 9521 \\ November 2015}

\author{
IZA \\ P.O. Box 7240 \\ 53072 Bonn \\ Germany \\ Phone: +49-228-3894-0 \\ Fax: +49-228-3894-180 \\ E-mail: iza@iza.org
}

\begin{abstract}
Any opinions expressed here are those of the author(s) and not those of IZA. Research published in this series may include views on policy, but the institute itself takes no institutional policy positions. The IZA research network is committed to the IZA Guiding Principles of Research Integrity.

The Institute for the Study of Labor (IZA) in Bonn is a local and virtual international research center and a place of communication between science, politics and business. IZA is an independent nonprofit organization supported by Deutsche Post Foundation. The center is associated with the University of Bonn and offers a stimulating research environment through its international network, workshops and conferences, data service, project support, research visits and doctoral program. IZA engages in (i) original and internationally competitive research in all fields of labor economics, (ii) development of policy concepts, and (iii) dissemination of research results and concepts to the interested public.
\end{abstract}

IZA Discussion Papers often represent preliminary work and are circulated to encourage discussion. Citation of such a paper should account for its provisional character. A revised version may be available directly from the author. 
IZA Discussion Paper No. 9521

November 2015

\begin{abstract}

\section{Entrepreneurship and the Reallocation of African Farmers*}

African agriculture's importance for sustainable development is well appreciated. Indeed, recent years have seen a thorough reappraisal of the sector. What are less well understood, however, are the drivers that reallocate scarce human and physical resources across occupations and space, and without which agriculture and industrial development, and hence structural transformation, will stagnate. One such endogenous driver is entrepreneurship. In this paper I start with the reappraisal of African agriculture and focus on the literature on entrepreneurship in Africa's structural transformation. I present a conceptual model to describe how entrepreneurship reallocates farmers out of agriculture into non-agricultural activities and locations. Recent empirical evidence that is broadly consistent with this model is discussed. Implications and challenges for entrepreneurship development policies and further research are outlined.
\end{abstract}

JEL Classification: Q12, J43, L26, M13, 055, O13

Keywords: agriculture, entrepreneurship, Africa, development, industrialization, structural change, urbanisation

Corresponding author:

Wim Naudé

Maastricht School of Management

PO Box 1203

6201 BE Maastricht

The Netherlands

E-mail:w.naude@maastrichtuniversity.nl

* Delivered as the Simon Brand Memorial Lecture, Agricultural Economics Society of South Africa, Khaya Ibhubesi, Vredefort Dome, South Africa, 30 September 2015. 


\section{Introduction}

A country's income per capita can only increase over time if the productivity of its labour and capital continues to grow. Hence, productivity growth is a central requirement for poverty reduction, catching-up and development (Hall and Jones, 1999). For African countries, still amongst the poorest, lagging development is the result of low productivity levels and slow productivity growth over time. Why this has been the case has generated a substantial literature (see e.g. Acemoglu and Robinson, 2011; Bosker and Garretsen, 2012; Collier and Gunning, 1999; Gennaioli and Rainer, 2007; Jerven, 2010; McMillan and Harttgen, 2014).

Underlying the continent's low levels and growth of labour productivity is the fact that it has failed to structurally transform. Most advanced countries and regions have developed through a process of structural transformation, during which resources are allocated away from traditional, low-productive activities towards modern, productive activities, most often located in urban areas. As far as Africa is concerned however, there is consensus that most of its countries remain structurally dependent on ruralbased agricultural activities and that most have failed in terms of industrial development, and urbanization ${ }^{1}$ (see e.g. Christiaensen and Chuhan-Pole, 2015; De Vries et al., 2013; Lele et al., 2015; McMillan and Heady, 2014; Rodrik, 2014). Even worse: as McMillan and Heady (2014) document, structural change in Africa has been such between 1990 and 2005 that it has reduced productivity growth; they conclude that 'labour seems to have moved from high to low-productivity activities on average, reducing Africa’s growth by 1.3 percentage points per annum on average’ (p.3).

The experience of Africa stands in stark contrast to that of China. Not only did China rose from an agriculturally dependent poor country to become the world's largest manufacturing exporter, it also achieved a quadrupling of real per capita incomes in its rural areas between 1978 and 1985. This was the result of a huge reallocation of farmers into the non-farm sector (Yang, 2004). Furthermore huge migration flows from rural to urban areas established competitive manufacturing cities where poverty fell significantly (Lin and Yu, 2015).

As a result of a lack of significant structural transformation, essentially a failure to reallocate its farmers into non-farm rural activities and urban centres, not only have African economies failed to eliminate poverty and reduce vulnerability to food and input price shocks, but also have these economies remained stuck with an unproductive farming sector (Heady and Jayne, 2014; Fuglie, 2010). Low farm productivity jeopardises food security, poverty alleviation, and restrict African

\footnotetext{
1 Urbanization is a prerequisite for development (Zhang, 2002). Africa's population is still predominantly rural, there are few megacities, and population density is low compared to more economically developed continents lack (Ndulu et al. 2007b).
} 
farmers to benefit or exploit the opportunities that currently exist in global food markets $^{2}$ (Collier and Dercon, 2014). Moreover, low farm productivity can create a development trap since it means that proportionately more labour in rural Africa needs to be devoted to farming just to ensure that subsistence levels are met (Schultz, 1953).

African development thus hinges on farming, and specifically on reallocating farmers to the rural non-farm sector, and to urban areas. Given that large productivity gaps exist between agriculture and non-agriculture in Africa, and between urban and rural labourers, the benefits for productivity growth from reallocation of farmers out of agriculture will be substantial (see also Gollin et al., 2014). Moreover as Christiaensen and Naudé (2015) point out, growing urbanization, rising incomes, and expectations of higher food and energy prices in future imply a large and localized market for agricultural products that can benefit the entire agrifood industry in Africa is productivity can be improved.

In this paper I argue that rural non-farm entrepreneurs can play a role in this reallocation. To be specific, more farmers and future rural job seekers need to be accommodated in the rural non-farm sector and in secondary cities and towns. In this I propose a refinement of standard models of thinking about structural transformation and rural-urban migration, such as the Lewis-model and Harris-Todaro model. In these 'working-horses' of development economists, the dichotomies are too simple: either between rural and urban, where urban refers to mega-cities or primary cities; and between the modern, formal sector and farming. Rural non-farm entrepreneurs presents an important in-between mechanism for these process of reallocation between occupations and locations, and one that can be missed in policy and planning if the strict dichotomy between urban and rural is kept.

The essential argument I make is that rural non-farm entrepreneurs can contribute to reallocating more labour into higher productive activities, which could in turn raise labour productivity on farms, raise rural incomes, and foster rural densification and secondary city agglomerations which would facilitate structural transformation. This role is particularly important in Africa, where geographical features, including large distances, low population densities and rugged terrain often create barriers to market access, and hence specialization in either agriculture or manufacturing (Bosker and Garretsen, 2012; Naudé, 2009; Nunn and Puga, 2012).

I present my case as follows. In section 2 I make a case for the reallocation of African farmers. In section 3 I present a theoretical model to introduce the entrepreneur into a Lewis-model of structural transformation, and illustrate why the role of entrepreneurs are potentially important (despite being relatively neglected by scholars) in rural transformation. In section $4 \mathrm{I}$ set out some supporting evidence based on recent analyses of the LSMS-ISA dataset, which for the first time offers comparable data

\footnotetext{
${ }^{2}$ Global food production need to double by 2050 to provide enough for world population of 9 billion by then. This is an opportunity for African agriculture, seeing that Africa is the continent where there is the largest gap between current and potential crop yields.
} 
across six African countries on rural non-farm entrepreneurship. Finally, in section 5 I conclude with recommendations for policy and further research.

\section{Why African Farmers need to be reallocated}

Structural change requires resources to be re-allocated away from low towards high productivity sectors, including moving the location of production where productivity is higher, such as in cities. As I stated in the introduction, there is general consensus that Africa has failed over the past fifty years to so to make meaningful structural economic transformation. How valid or accurate is this consensus? How much different is productivity in Africa, including African agriculture? Does Africa have the potential to achieve the productivity gains required for catching-up growth?

In this section I attempt to answer these questions by providing reviewing the current structure of African economies, and noting the profile and determinants of labour productivity across sectors, and particularly in farming.

\subsection{Structure and structural change in Africa}

Most labour in Sub-Saharan Africa is employed in sectors and firms where productivity is low. Figure 1 depicts that in Africa most labour is employed in agriculture (59.2 per cent) but moreover that 78.2 per cent of the 'working poor' is employed in agriculture. This is much more than in other developing countries and reflect the fact that productivity levels (and hence wages) are very low.

Figure 1: Sectoral employment in Africa and other developing countries (population weighted averages 2002-2012)

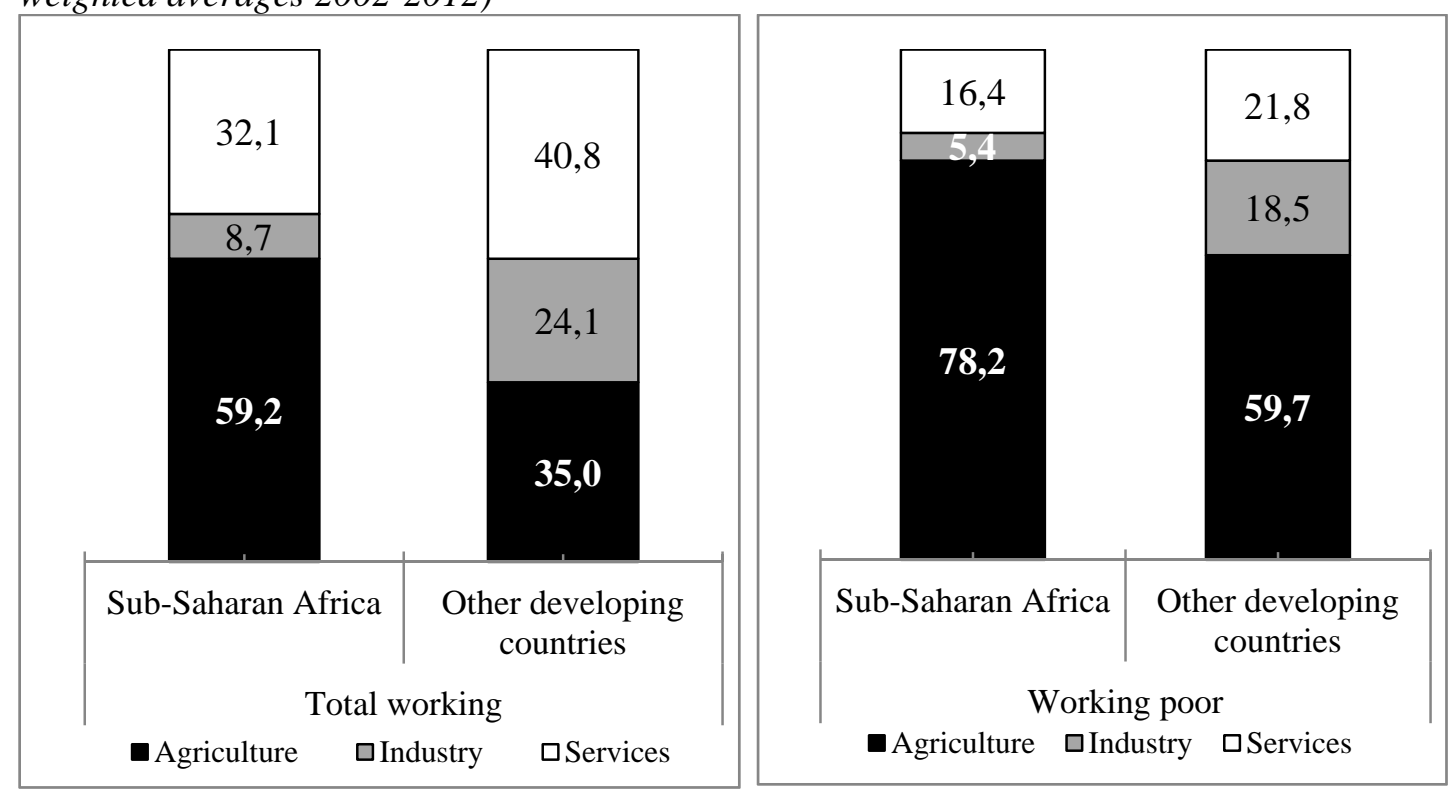

(Source: Christiaensen and Chuhan-Pole, 2015, based on Africa's Pulse vol. 10. International Income Distribution Database) 
Figure 1 depicts the population-weighted averages of employment per broad sector in Africa over 2002-2012. This hides however changes in the structure over time. Labour allocation has not been static. In this regard Figure 2 compares a sample of countries from Sub-Saharan Africa with samples from Asia and Latin America, showing that productivity growth rates from 1990 has been lowest in Africa, with some countries experiencing decreasing productivity.

Figure 2: Productivity, compounded annual growth 1990-2005 in selected emerging economies (\%)

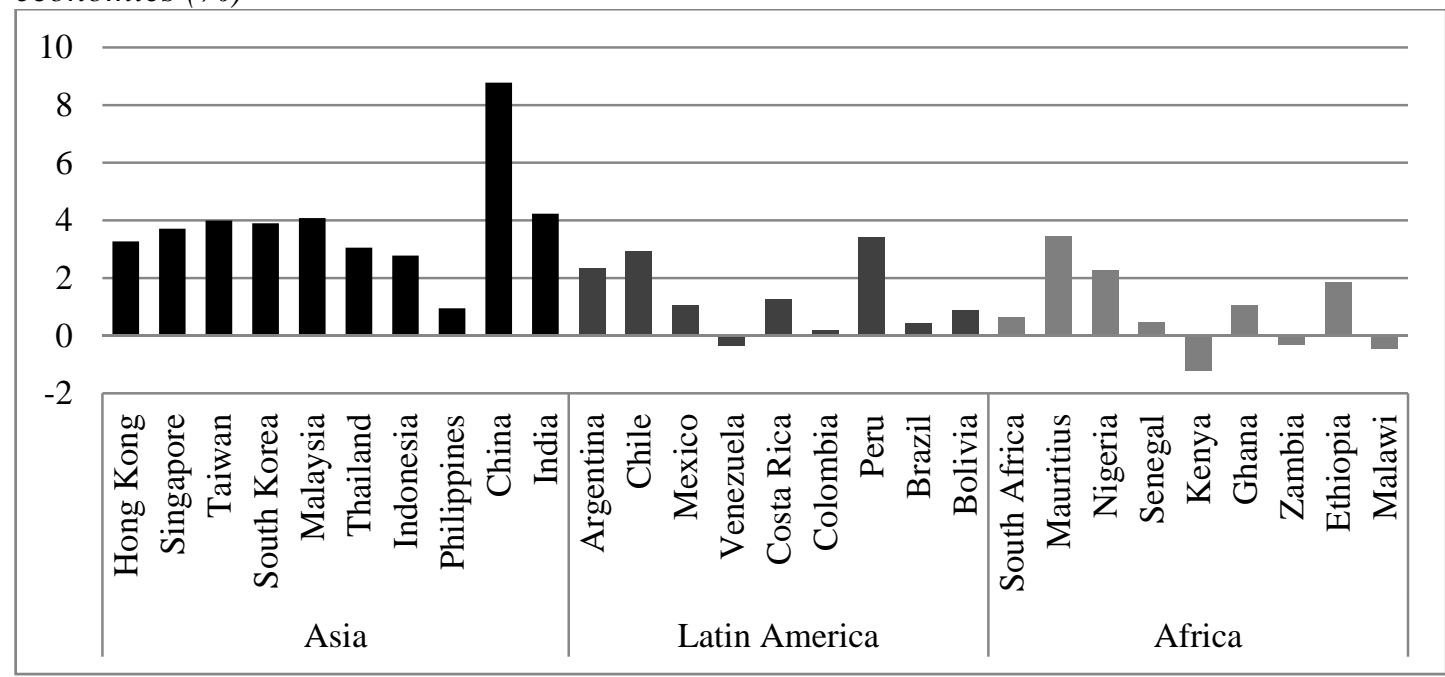

(Source: Based on data from McMillan et al 2014: Table 1 p. 13)

The labour productivity growth depicted in Figure 2 is calculated as the 'weighted sum of the labour productivity growth within sectors and the productivity growth due to labour reallocation between sectors' (Christiaensen and Chuhan-Pole, 2015). It is instructive to consider whether labour productivity growth that did take place in Africa in recent times has been due to within-sector growth, or due to labour reallocation, keeping in mind that large productivity gains can be generated from reallocating labour out of agriculture and rural areas. This is done in Figure 3, which shows the contributions to growth in labour productivity in sample of African countries between 1985 and 2009.

Figure 3 illustrates that African labour productivity growth is driven by productivity growth within sectors, and not between sectors. In other words, it is not structural change that is driving productivity growth in most countries. As such, concerns have been expressed about the sustainability of recent economic growth rates in Africa (Christiaensen and Chuhan-Pole, 2015; Rodrik, 2014). 
Figure 3: Contributions to annual labour productivity growth in selected African countries, 1985-2009

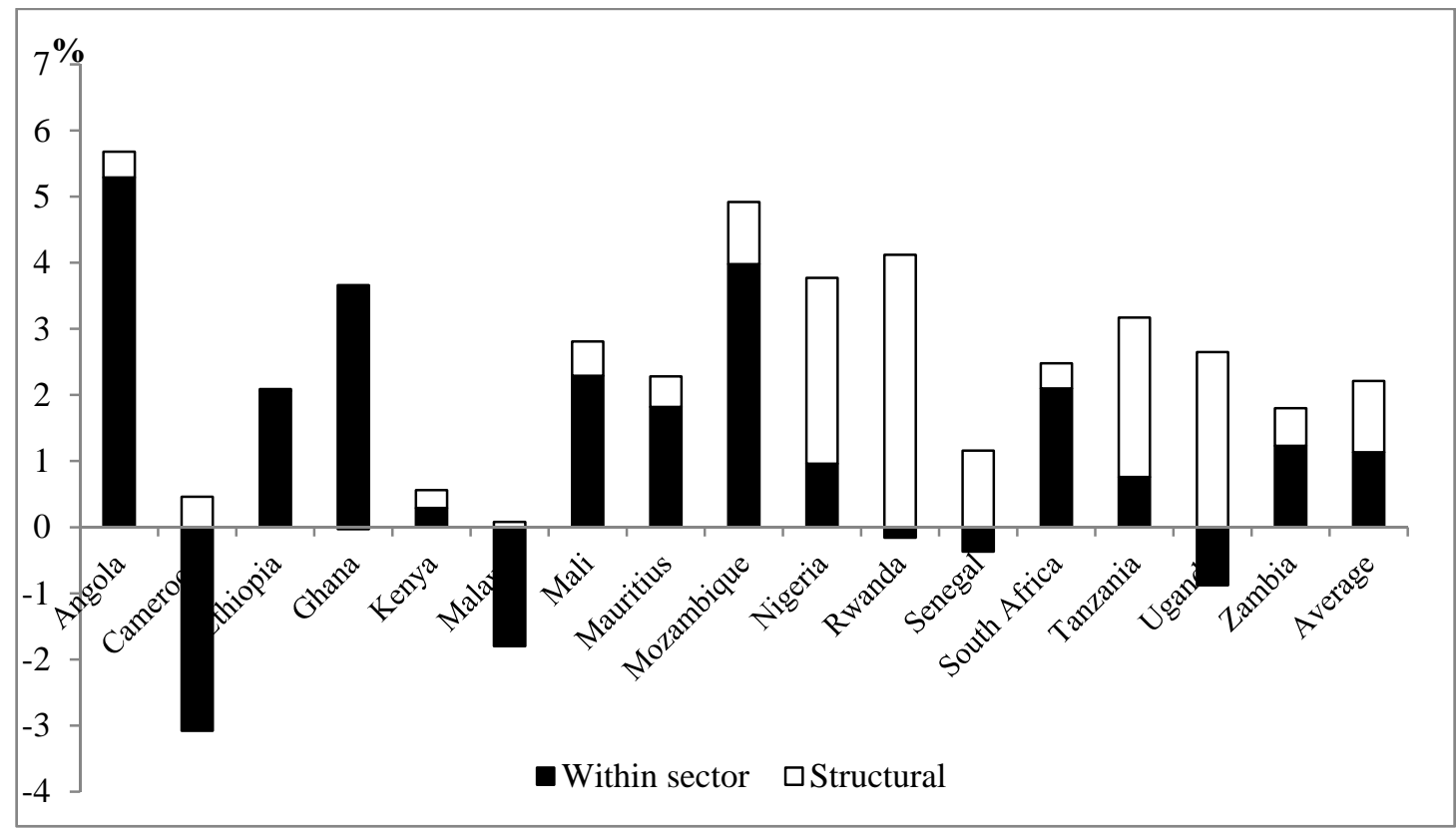

(Source: McMillan and Harttgen, 2014)

Although structural change is not driving productivity growth there has in fact been a structural shift in Africa since the 1990s, from agriculture to services, which is not shown in Figures 2 or 3. As McMillan and Rodrik (2011), De Vries et al. (2013) and McMillan et al. (2014) have documented, these changes have led to slower productivity growth since the 1990s. McMillan and Rodrik (2011) label this 'productivity-reducing structural change' and De Vries et al. (2013) describe it as 'static gains but dynamic losses'. Christiaensen et al (2011) reports that while labour productivity in agriculture in Africa grew on average with the low rate of 0.9 percent annually between 1960 and 2003, labour productivity growth in non-agriculture was slower - in fact negative at -0.7 percent per year on average over this period.

Figure 4 shows the changes in employment in Sub-Saharan Africa in the more recent period 2005 to 2010. Its shows a shift in employment from agriculture to services, including to household enterprises. The share of the labour force employed in African agriculture dropped from 65.2 per cent in 2005 to 59.3 per cent in 2010. Employment in industry however stayed relatively constant, and employment in services increased only marginally. The most significant increase has been in the share of household enterprises in employment: up to 21.4 per cent from 17.1 per cent ${ }^{3}$. According to the scholars mentioned, these shifts are into sectors where productivity growth is slower

\footnotetext{
${ }^{3}$ In South Africa, the continent's most advanced economy, similar trends were experienced. Agricultures contribution to total employment declined from 4 per cent in 2005 to 3.6 percent in 2010. The share of household enterprises increased from 9.8 per cent to 11.4 per cent and of services from 42.6 to 45 percent over the same period. Industry's contribution to employment, as elsewhere in Africa declined: from 16.3 per cent in 2005 to 14.8 percent in 2010 (Fox et al., 2013).
} 
than in industry. In section 4 I will look more critically at this by sharing some new data on household enterprise productivity from Nagler and Naudé (2014).

Figure 4: Sectoral employment shifts in Sub-Saharan Africa, 2005 to 2010 (\%)

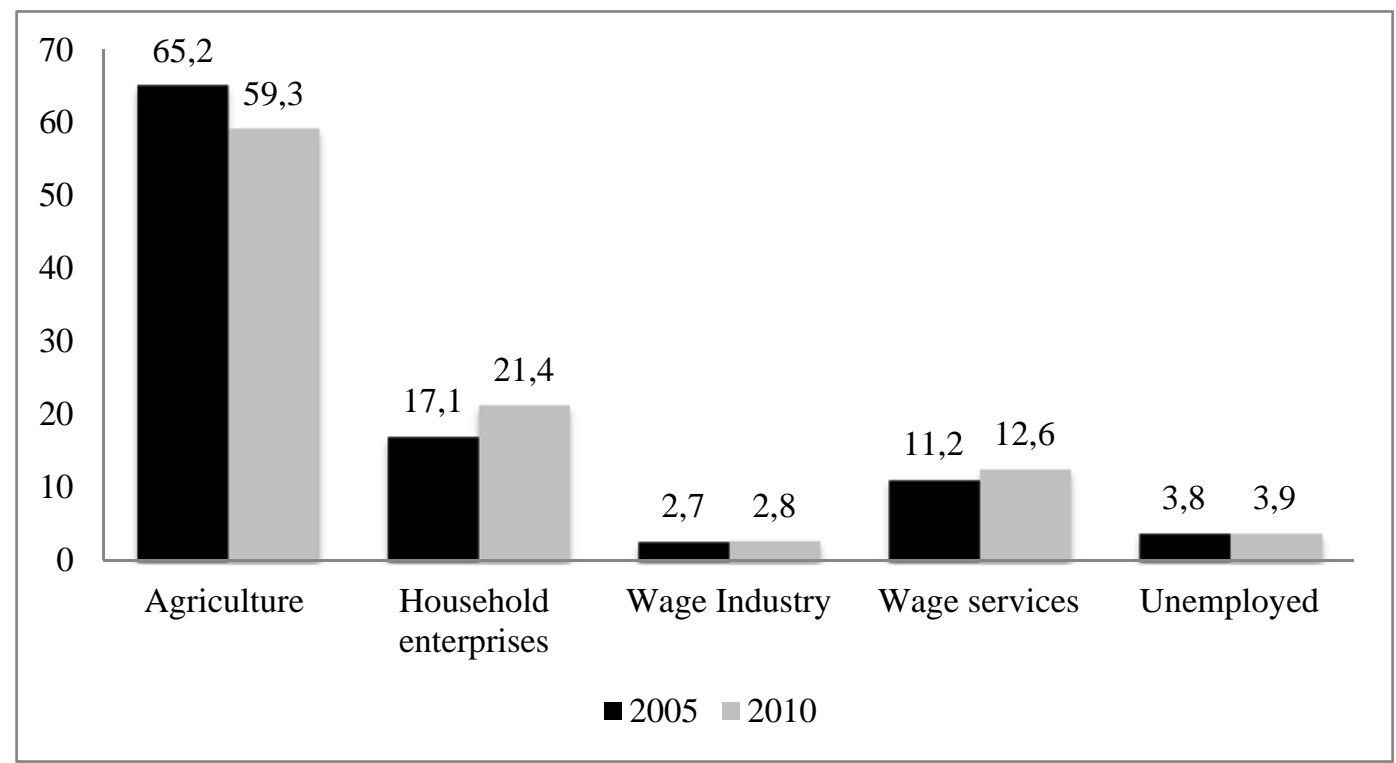

(Source: Based on data from Fox et al. 2013, p.36)

Thus although the re-allocation of labour from agriculture to services (including household enterprises) has raised average productivity once off (static gains) during the 1990s and 2000s (Figures 2 and 3), subsequently inter-sectoral (services) growth in productivity was slow and even negative (dynamic losses). Timmer et al. (2014:8) also conclude that structural change in Africa has resulted in 'de-industrialization in terms of a falling share of manufacturing in GDP since the mid-1970s'. Page (2013:251) notes that between 1975 and 2005 'the sophistication of the manufacturing sector in 16 of the 18 African economies in the UNIDO database declined relative to predicted values'.

To understand the failure of structural change that drives labour productivity growth, one needs to better understand labour productivity and its patterns and determinants in Africa. The focus on labour productivity (a partial productivity measure) is because it is important for wages and incomes, and hence poverty reduction and welfare improvements.

\subsection{Labour productivity in Africa}

Labour productivity (output per worker) in Africa is widely dispersed, between but also within sectors and occupations, and across regions and localities. This dispersal of labour productivity across occupations and space provides a framework for summarising the four salient characteristics of labour productivity in Africa.

Firstly, productivity is lower in agriculture than in non-agriculture. This is also to an extent true for other regions, but the gap is highest in Africa. Gollin et al (2014:971) present global estimates, covering 151 countries, of the gaps in productivity between 
agriculture and non-agricultural sectors. Measuring productivity as value added per labourer, they find that 'even after adjustments for hours and human capital, the agricultural productivity gaps are still large in most countries, and particularly so in the developing countries' (Ibid, p. 971). For instance, in advanced economies the mean ratio of value added per labour in non-agriculture to agriculture is 1.7, compared to the poorest countries where the mean ratio is $3.0^{4}$. It may even be higher in Africa; as reported by McMillan and Heady (2014) output per labour in African agriculture in 2005 was $\$ 486$ compared to $\$ 3770$ in non-agriculture - hence nonagriculture was perhaps 7.7 times more productive!

Vollrath (2009) reports that in 1985 the marginal product of labour in industry to the marginal product of labour in agriculture was 16.8 in Kenya, 13.7 in Malawi, 11.9 in Zimbabwe and 9.3 in South Africa. He concludes from this that 'income per capita could be two and a half times larger in Malawi and Kenya if physical and human capital were reallocated to the higher productivity industrial sector' (p.330). The countries with more workers agriculture are also the countries where the labour productivity in agriculture is lower (see Figure 5). This is evidence of a misallocation of labour.

Figure 5: Labour (mis-) allocation and productivity in African agriculture, 2005

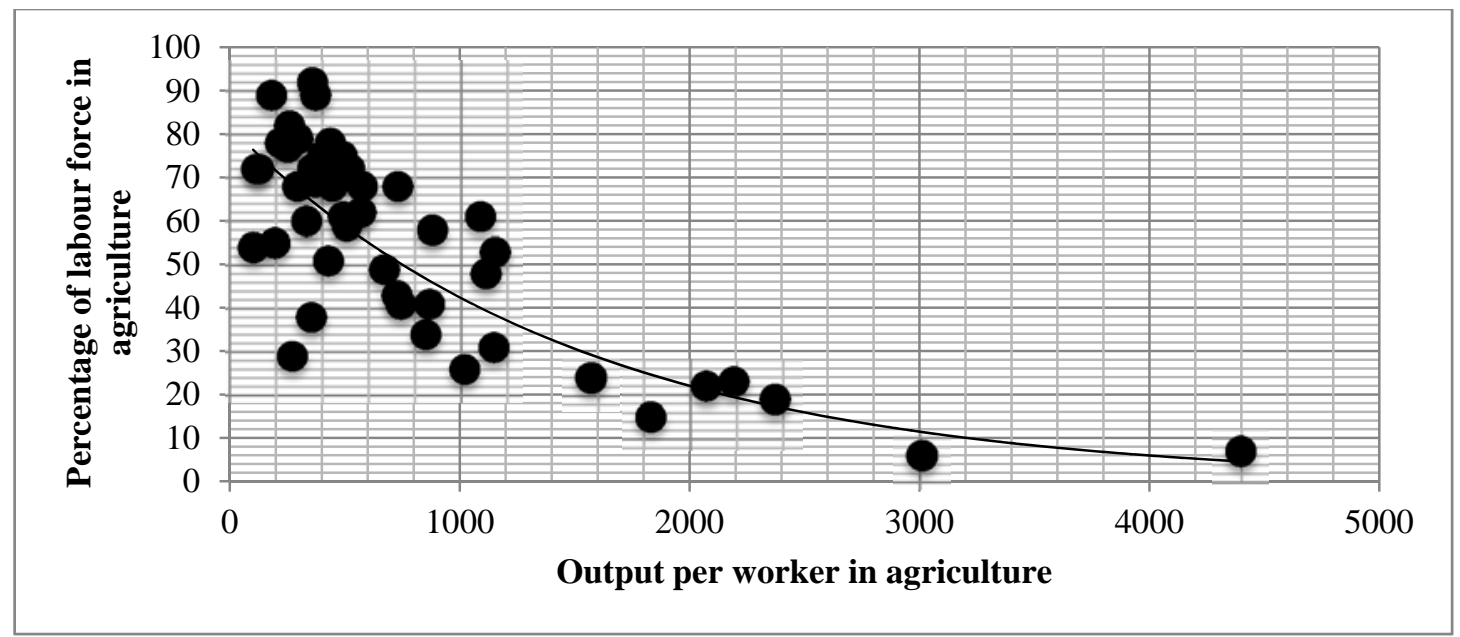

(Source of data: McMillan and Heady, 2014)

As well as being low in levels, labour productivity in African agriculture has grown very slowly over the past fifty years. According to Fulginiti et al. (2004), using data from 41 countries, productivity growth in African agriculture between 1960 and 1999

\footnotetext{
${ }^{4}$ In case of South Africa, using 1993 data, Gollin et al (2014:977) calculates the ratio of value added per nonagricultural labour to agricultural labour to be 2.3 when using macro-data, and 1.7 when using micro-data. This is very similar to that of Ghana in 1998 (2.2 and 2.3 respectively) although in South Africa only 11 per cent of the labour force was employed in agriculture in 1993 compared to 53 per cent in Ghana in 1998.
} 
was only 0.83 percent annually on average $\mathrm{e}^{5}$. This is similar to the labour productivity growth of 0.9 percent annually on average estimated by Christiaensen et al. (2011) for the period 1960 to 2003.

Second, within agriculture productivity is widely dispersed within sectors ${ }^{6}$ (Christiaensen and Kaminski, 2014). Indeed productivity gaps tend to be higher within agriculture than within non-agriculture (Lagakos and Waugh, 2013).

Third, while non-agricultural activities are more productive than agricultural activities in Africa, the productivity of non-agricultural activities in Africa lag behind those in other regions. For instance, non-farming firms in African countries formal sector have been found to have labour productivity that is $48 \mathrm{log}$ points lower compared non nonAfrican countries at similar levels of development, with labour productivity growing 8.6 per cent slower. Compared to advanced economies the differences are even greater (Harrison et al., 2014). Also here firm-level heterogeneity in productivity levels is found (Nagler and Naudé, 2014). Exporting, urban-based, formal and larger non-agricultural firms tend to be overall more productive (Rijkers et al., 2010; Söderbom and Teal, 2004; Van Biesebroeck, 2005). Firm-level heterogeneity in productivity levels is generally considered an indicator that there is a misallocation of resources (Bartelsman et al., 2013). In developing countries within-sector productivity dispersion is higher than in advanced economies ${ }^{7}$ (Hsieh and Klenow, 2009).

Fourth, labour productivity in non-agricultural activities are dispersed across space in Africa, as it is elsewhere. In particular, urban labour is more productive than rural labour. Productivity gaps between rural and urban firms are significant (based on rather limited data, however). Rijkers et al (2010) using Ethiopian data find that the output: labour ratio for non-agricultural firms in remote rural areas is 0.43 , that it is higher in rural towns and secondary cities (0.95), and that in urban areas it rises to its highest at 2.30 (Rijkers et al., 2010:1282).

\subsection{Why is labour productivity lagging in Africa?}

The immediate determinants of labour productivity, and the patterns noted in section 2.2 are many. They include skills and matching of skills with appropriate technologies, and access to and use of sophisticated inputs and support services (see Syverson, 2011). In the case of agriculture these would include 'technologies' like

\footnotetext{
${ }^{5}$ Liebenberg (2013) summarizes various estimates of labour productivity growth in South African agriculture. These range between 2.68 and 2.76 per cent per annum on average between 1910 and 2010.

${ }^{6}$ This is a feature not only of agriculture productivity in Africa, but also elsewhere, even in advanced economies. For instance, Rabobank (2013:55-56) note that in Dutch diary farming, the 'top 25\% Dutch diary farmers are able to achieve about $45 \%$ higher milk yields per cow that the $25 \%$ least productive local colleagues'.

${ }^{7}$ Hsieh and Klenow (2009) calculate that total factor productivity in China and India would increase by between 30 and 60 per cent if these countries would re-allocate their resources more similarly to that of the USA.
} 
fertilizer, mechanization, water management and extension services (Haggblade, 2013). Where these determinants result in low labour productivity and varying spreads in productivity even within sectors as observed in Africa (and both in agriculture and non-agriculture as documented above) it reflects the general misallocation of resources that fails to equip labour with adequate complementary technology. Vollrath (2009) estimates that 30 to 40 per cent of differences in per capita incomes between countries is a result of the misallocation of resources. Too many resources are allocated to agriculture in poor countries (see Figure5 illustrating this for the case of Africa).

This misallocation comes about for a number of reasons. Generally, Caselli and Coleman (2001) explain this as arising due to frictions and obstacles that hinder the reallocation of labour from agriculture to manufacturing. Indeed, the question has been asked why don't more people migrate out of Africa's rural areas and farms to cities and to non-farm occupations, given the large productivity dividend that such a re-allocation could result in? (De Brauw et al., 2014; Beegle et al., 2011)

In section 3 I will introduce a theoretical model that illustrate how various frictions can hinder the reallocation of farmers (and migration to cities) and result in rural stagnation, and discuss the role of rural non-farm entrepreneurs (household enterprises) in this process. For now however, I discuss a number of frictions or obstacles to the reallocation of farmers to manufacturing and cities that have been identified in the literature. These frictions explain why labour productivity is lagging in Africa.

\subsubsection{Business environment}

Most authors ascribe frictions as due to the difficult business environment that farmers and entrepreneurs face in Africa. For instance McMillan and Heady (2014) and Vollrath (2009) discuss high risks and transaction costs, asymmetric information and policy distortions as causes of low labour productivity. According to Harrison et al (2014) the labour productivity gap between African non-agricultural firms and firms elsewhere, is caused by a difficult environment to conduct business in, particularly due to lack of finance, political uncertainty and poor infrastructure. These obstacles they argue, limit the reallocation of labour from agricultural into manufacturing much more than into services, which explain why, as was shown in section 2.1, Africa's structural stagnation has been accompanied by growing employment in the services and household enterprises sector (see Figure 4).

Various studies, based on World Bank data on (formal) non-agricultural firms, have suggested that a poor business environment is responsible to low labour productivity and growth in African non-agricultural firms (e.g. Arnold et al., 2006; Dethier et al., 2010; Dollar et al., 2005; Eifert et al., 2008). Harrison et al (2014:59-60) finds in fact that 'if we control for infrastructure, access to finance, the political and business environment, African firms lead in productivity levels and growth rates'. 


\subsubsection{Factor market distortions}

There are also important factor market distortions, in labour and capital markets, that keep farmers stuck in low-productive agriculture. The first kind of distortions, in labour markets, result in a mismatch between abilities and occupations - i.e. an occupational mismatch. According to Lagakos and Waugh (2013) labourers selfselect into agriculture in poor countries in order to meet their subsistence food consumption requirements. Because most of these labourers are not inherently good at farming, their productivity is low, which means even more labour needs to be allocated to farming to meet overall subsistence needs. They posit that workers who do not have to select into farming tend to be better matched with their jobs and hence more productive, causing also productivity levels to be less dispersed. This occupational mismatch implies that skills levels in non-farming sectors should be higher than in farming on average, in poor countries, an implication that is borne out by data (see Beegle et al., 2011; Miguel and Hamory, 2009). It also implies that, because skill levels or occupational matches are ex ante unobservable by financial institutions, that credit extension to farmers would be rationed, as banks or financiers cannot distinguish a potentially good farmer from a farmer with less ability (see Stiglitz and Weiss, 1992).

\subsubsection{Geographical disadvantages ${ }^{8}$}

The misallocation of resources into African agriculture is also due to the geographical conditions that African farmers and entrepreneurs face. Most importantly for present purposes are the impacts of natural hazards such as drought and floods on agriculture, and the impacts of (limited) market access on both farm and non-farm productivity (Haggblade, 2013).

As far as natural hazards are concerned, some geographic areas are more subject to drought or to constraining soil conditions. Africa has the lowest share of irrigated agricultural land in the world, partly a result of a relative lack of large rivers and alluvial plains (Sachs et al. 2004). Seasonality, inherent in agriculture and magnified by lack of irrigation, increases transport costs and hence reduces market access.

Irregular rainfall, which makes prediction of crop sizes difficult, also raises transactions costs and reduces market access (Williams 2007). The kind of imports and exports that dominates African trade (including fertilizer imports) generally are subject to higher freight rates than other goods (Hummels 1999). And labour, concentrated in agriculture (see section 2) is negatively affected by a heavy disease burden, including from malaria, which undermines productivity and capacity building (Easterly and Levine, 2003).

The previous paragraphs suggest that geography ultimately limits market access by raising transport costs. Indeed the empirical evidence bears this out transport costs are significantly higher in Africa than elsewhere. Naudé and Matthee (2007) found that

\footnotetext{
${ }^{8}$ This section partly relies on Naudé (2009).
} 
international transport costs to and from African countries to be basically twice as high as the world average. Adamopoulos (2011) found that freight rail is 10 times more expensive in Uganda and Mali than in the United States. He shows that low transport productivity and high transport costs makes agricultural trade in Africa unprofitable and hence contribute to the misallocation of resources, as it limits specialization, and limits the use of sophisticated inputs (see also Kariuki, 2011). Using a CGE model Adamopoulos (2011) calculates that if the advanced economies had the same transport productivity of African countries their GDP would be 10 per cent lower.

\subsubsection{Entrepreneurial skills and management practices}

A final reason for lagging labour productivity and within-sector productivity spreads is that entrepreneurial skills and management practices may matter. Typically, entrepreneurship and management practices have not been given much attention in the explanation of productivity levels, dispersion and growth in Africa. Recently there has been a gradual change in this, with some scholars finding that these practices matter significantly for productivity outcomes.

Heady and Jayne (2014) find that despite growing population pressure and smaller farm sizes ${ }^{9}$, African farmers have generally failed to introduce more intensive use of fertilizer and irrigation, and have lagged behind in mechanisation. Why have they failed in this? While access and cost and institutional obstacles (the business environment) no doubt provide part of the explanation, it is increasingly recognised that managerial competencies and practices are important for the uptake of technologies on the firm level.

Bloom and Van Reenen (2010), considers management itself a type of 'technology'. Using a large dataset across the world that includes various measures of management practices ${ }^{10}$ they explain productivity differences in large firms. Managerial capacity is an important determinant of the extent to which technology penetrates into firms, with better managers being able to much more efficiently introduce technology into their firms and promote innovation (Bloom and Van Reenen, 2010).

McKenzie and Woodruff (2015) extends this finding also to small firms in developing countries, finding that business practices is a significant factor explaining productivity in small firms in samples from developing countries. Including in African countries such as Ghana, Kenya and Nigeria.

\footnotetext{
${ }^{9}$ Moreover with its still high population growth, land scarcity is becoming significant in many African countries: average farm size in twelve of Africa's most populous countries have declined from 2 to 1.2 hectares over the past three decades (Heady and Jayne, 2014).

${ }^{10}$ They measure management practices using 18 indicators that respondents had to rank on a 1 to 5 scale, focusing on monitoring, targeting, and incentives in management.
} 
In the next section I tie together the different explanations for lagging labour productivity in Africa with a model of structural transformation, wherein the innovative and risk-taking behaviour of entrepreneurs play a central role.

\section{The Role of Rural Entrepreneurs in Structural Transformation ${ }^{11}$}

In this section I reproduce a simplified and slightly modified model of entrepreneurship and structural transformation that was first proposed by Gries and Naudé (2010). Their paper contains the formal derivation of propositions hence in what follows I will only attempt to explain the salient features of the model, which is for present purposes the role of non-farm household enterprises as providing a mechanism for the reallocation of surplus labour out of agriculture to non-agriculture, and in so doing setting in motion the process of structural transformation. The comparative statics of the model, explained with the help of Figure 6, helps to identify the conditions that drive the success or failure of this transformation and links the entrepreneurial ability and finance available to household enterprises as essential in driving labour productivity gains in all sectors.

\subsection{Rural and non-rural sectors}

A salient characteristic of Africa's rural areas is its relatively large and growing population. Following Gries and Naudé (2010) I denote the population in rural areas to consist of $L$ number of people each earning an income $w$ and a number $\Delta_{T}$ that earns no income. Total population in the rural economy can be written

$$
\operatorname{Pop}_{T}=L+\Delta_{T}=L\left(1+\delta_{T}\right) \text {, with } \delta_{T}=\Delta_{T} / L
$$

Where $\delta_{T}$ denotes the ratio of unemployed to employed labour in the rural economy.

Rural population growth depends on per capita income of rural households, denoted by $y_{T}$. The precise relationship between population growth and incomes and can be written as:

$$
\gamma_{L} \equiv \frac{\dot{L}}{L}=g_{L}\left(y_{T}\right)=y_{T}^{\varphi} \text { with } \varphi<0
$$

Where $\varphi$ is the elasticity of population growth with respect to per capita income in the rural areas. With $\varphi<0$ it implies that as household incomes increases, population growth will slow as a demographic shift sets in.

From the latter we can deduced that rural population growth is a negative function of unemployment $\delta_{T}$ and a positive function of average labour productivity $\left(a_{T}\right)$ :

\footnotetext{
${ }^{11}$ This section draws on Gries and Naudé (2010).
} 


$$
\begin{aligned}
\gamma_{L} & =\left(\frac{a_{T}}{\left(1+\delta_{T}\right)}\right)^{\phi} \\
& =g_{L}\left(\delta_{T}, a_{T}, \phi\right) \text {, with } \frac{d g_{L}}{d \delta_{T}}<0, \frac{d g_{L}}{d a_{T}}>0, \frac{d g_{L}}{d \phi}>0
\end{aligned}
$$

Unemployed labour can be searching for wage-employment on farms or for opportunities for self-employment (entrepreneurship) in the modern, non-agricultural economy. If such an opportunity is spotted and successfully taken up, the person will and migrate to the modern sector and leave the rural area. Hence, migration out of farms and out of farming areas is a critical structural transformation mechanism.

The non-agricultural sector consist of large formal firms and small, informal firms. Large formal firms are typically owned either by foreigners (multinational firms) or the government. These firms produce final goods $(Y)$ for consumption in both urban and rural areas using human capital $H$ and $N$ intermediate inputs $x_{j}$, which they will outsource to the $N$ small household enterprises. The production function for the representative large formal firm producing for the final goods market is:

$$
Y=A H^{1-\alpha} \sum_{j=1}^{N}\left(x_{j}\right)^{\alpha}=A H^{1-\alpha} N x^{\alpha}
$$

In equation (4) $A$ is a technology shift-parameter. Producers of the final good aim to maximize profits which are $\pi_{Y}=Y_{M}-w_{H} H-N p_{j} X_{j}$ where $p_{j}$ is the price of intermediate good $x_{j}$ and $w_{H}$ the returns on the entrepreneurial and managerial abilities of the owner of the formal firm. From the above we can derive the demand for each intermediate input as:

$$
x_{j}=H\left(\frac{A \alpha}{p_{j}}\right)^{\frac{1}{1-\alpha}}
$$

The demands for these $\mathrm{j}$ intermediate inputs constitute an opportunity for the people in rural areas, $P_{0} p_{T}$. Not all intermediate goods demanded constitute an opportunity, as some will already be taken by other household enterprises. The number of opportunities, $O$, in the modern sector is the number of opportunities for subcontracting to a formal large firm that has not yet been taken by existing household enterprises, and can be written as:

$$
O=\delta_{N} N
$$

Where $\delta_{N}=\Delta_{N} / N$ with $\Delta_{N}$ the number of business opportunities not yet exploited. If they spot these opportunities, $O$, households will form a (non-agricultural) household enterprise. These have been, as section 2 indicated, of increasing 
importance in Africa. Each will then produce a unique intermediate input that they sell to the large formal firms (in this I follow Ciccone and Matsuyama, 1996). The requirement that they each produce a unique input $x_{j}$ allows me to introduce innovation, start-ups, and start-up costs in the non-agricultural sector into the model, and hence ultimately deal with the obstacles in the reallocation of labour.

\subsection{Entrepreneurs, innovation and household enterprise start-ups}

If a household in rural areas spots an opportunity to provide a unique intermediate input $x_{j}$ to established large firms in the modern sector, it needs to create a new household enterprise. This involves incurring costs to differentiate the product to the needs of the large firm, and to finance the start-up and running costs of the household enterprise.

Gries and Naudé (2010) model start-up costs as a function of the density of household enterprises. The more density, the more competition and the more costly it is to enter the market. If there is $N$-number of household enterprises operating in the modern economy, and total output (GDP) in the economy is denoted with $Y$, then I can write the density of household enterprises as $N / Y$. Start-up costs as a function then is $\chi(N / Y)=\varepsilon \frac{N}{Y}$, with $\varepsilon>0$.

After incurring these start-up costs household enterprises will face continuous there running costs to keep operating. As in Gries and Naudé (2010) I denote these costs by $c_{x}$.

In rural Africa start-up cost are often financed by borrowing as most rural households have insufficient own financial -assets from which to finance this (see e.g. Bonnet et al., 2005).

The decision of a rural household on starting a household enterprises or not, depend on the expected profits in comparison to agricultural wages. Once the household enterprise has been started, profits are the difference between its sales (price times quantity) and operating costs, which is

$$
\pi_{j}^{x}=\left(p_{j}-c_{x j}\right) x_{j}
$$

Because start-up costs must be financed externally at an interest $r_{l}$ and because financial markets are thin and often missing in rural Africa I need to keep in mind financial markets imperfections. If there are $B$ number of banks with each bank $b$ taking $D_{b}$ deposits from households and making $K_{b}$ loans to new household enterprises then interest rates on loans and deposits will depend on the costs of monitoring loans $\left(c_{b}\right)$ and the competition in the banking sector, as measured by the number of different banks. 
Given the interest rate for start-up loans $r_{l}$, the expected net present value of the household enterprise is

$$
E V_{m}(\tau)=(1-\vartheta) \int_{\tau}^{\infty}\left(p_{j}-c_{x j}\right) x_{j} e^{-r_{d}(t, \tau)(t-\tau)} d t
$$

Where $\vartheta$ is the likelihood of business failure and $(1-\vartheta)$ the likelihood of success. The household will compare these expected profits (or net present value) to wages that can be earned from supplying labour to agriculture (denoted $E y_{T, i}$ ) in making its decision to start an enterprise.

If favourable, a new household enterprise will be started up. Because the start-up of a new household enterprise depend on the match between an entrepreneur in the rural sector and opportunities in the modern sector, entrepreneurial abilities, which can be denoted by $H$, are required to grab a business opportunity, $O$.

If there is a match, then a household enterprise is established. The number of household enterprises started every period is denoted by $\gamma_{N}$ and over time the growth of household enterprises is $\gamma_{N}=\dot{N} / N$. This is the speed of modernization in the model.

The higher the growth rate $\gamma_{N}$, the more people from rural areas will find employment in non-farm enterprises, and for those that remain in farming, average and marginal productivity will increase, leading to a rise in wage incomes in agriculture. The change in agricultural wages is $\gamma_{Y^{\top}}$. As per capita incomes (labour productivity) in agriculture grow then rural population will grow as per equation (2) and the traditional sector will expand. For structural transformation to occur, the growth of non-farm household enterprises must outpace the expansion of the traditional sector.

\subsection{Diagrammatic analysis}

The essentials of the model outlined so far can be graphically illustrated with the help of Figures 6 to 8. Figure 6 contains the basic model, depicting the relationship between the central variables outlined above.

The figures have four quadrants. Let us start with Figure 6. 
Figure 6: Entrepreneurship and structural transformation: Basic model

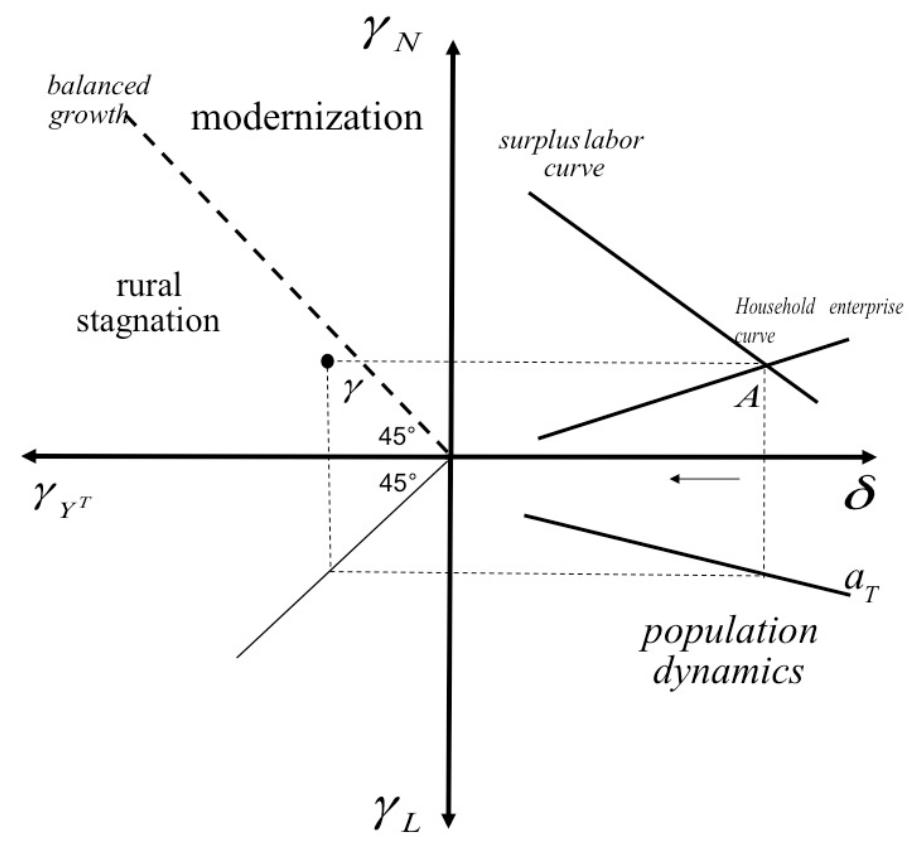

(Source: Based on Gries and Naudé, 2010)

In the northeast $\gamma_{N}-\delta$ quadrant the equilibrium values of $\gamma_{N}$ and $\delta$ that depend on the demand and supply of surplus labour in the non-farm economy is shown. The downward sloping curve (called the surplus labour curve) indicates that as the growth rate of non-farm household enterprises $\gamma_{N}$ increase, so surplus labour in rural areas will decline (hence the slope is negative). The upward sloping curve (which I call the household enterprise curve) depicts the converse, namely that the higher the rate of surplus labour that can be successfully extracted from the rural economy, the more household enterprises can be established.

The steady-state equilibrium is at $\mathrm{A}$, which determines the growth rate of the household enterprise sector and the surplus labour rate in the rural sector. At this point, the reallocation of surplus labour to the modern sector is too slow (reflected in the slopes and location of the two curves) so that the growth in the agricultural sector exceeds growth of the modern sector. Given the population growth rate, an initial equilibrium at point $\mathrm{A}$ is consistent with rural stagnation, in other words the size of the rural economy will grow relative to that of the non-farm economy, as $\gamma_{N}<\gamma_{Y^{T}}$.

Not enough farmers are reallocated via household enterprises to the modern sector. Structurally, the economy remains largely a rural, agriculture-based economy with low productivity, surplus labour in rural areas.

From the discussion above the growth rate of the number of household enterprises started, i.e. the slope and position of the household enterprise curve is a function of the endogenous surplus labour rate $\delta_{T}$, as well as the following determinants: 
- Productivity in agriculture $\left(a_{T}\right)$. If productivity in agriculture improves, then for a given population growth rate $\gamma_{L}$ there will be more surplus labour released, which will shift the population dynamics curve in the south east quadrant inwards and the surplus labour curve outwards, so that there will be growth in the number of household enterprises (see equation 3 ).

- Entrepreneurial ability $(H)$. Improvements in $\mathrm{H}$ will shift the household enterprise curve upwards, so that there will be growth in the number of household enterprises.

- Finance (B). Improvements in B will shift the household enterprise curve upwards, so that there will be growth in the number of household enterprises.

Improvements in these last two parameters, often the aim of policy interventions in rural Africa, are depicted in Figure 7. If entrepreneurial ability or access to finance improves the economy's structure transforms out of rural stagnation (at point $\gamma$ ) to a more modern economy (at point $\gamma^{\prime}$ ). This structural transformation will have resulted in an increase in productivity growth and hence per capita GDP.

Figure 7: Entrepreneurship and structural transformation: Improving entrepreneurial ability and finance

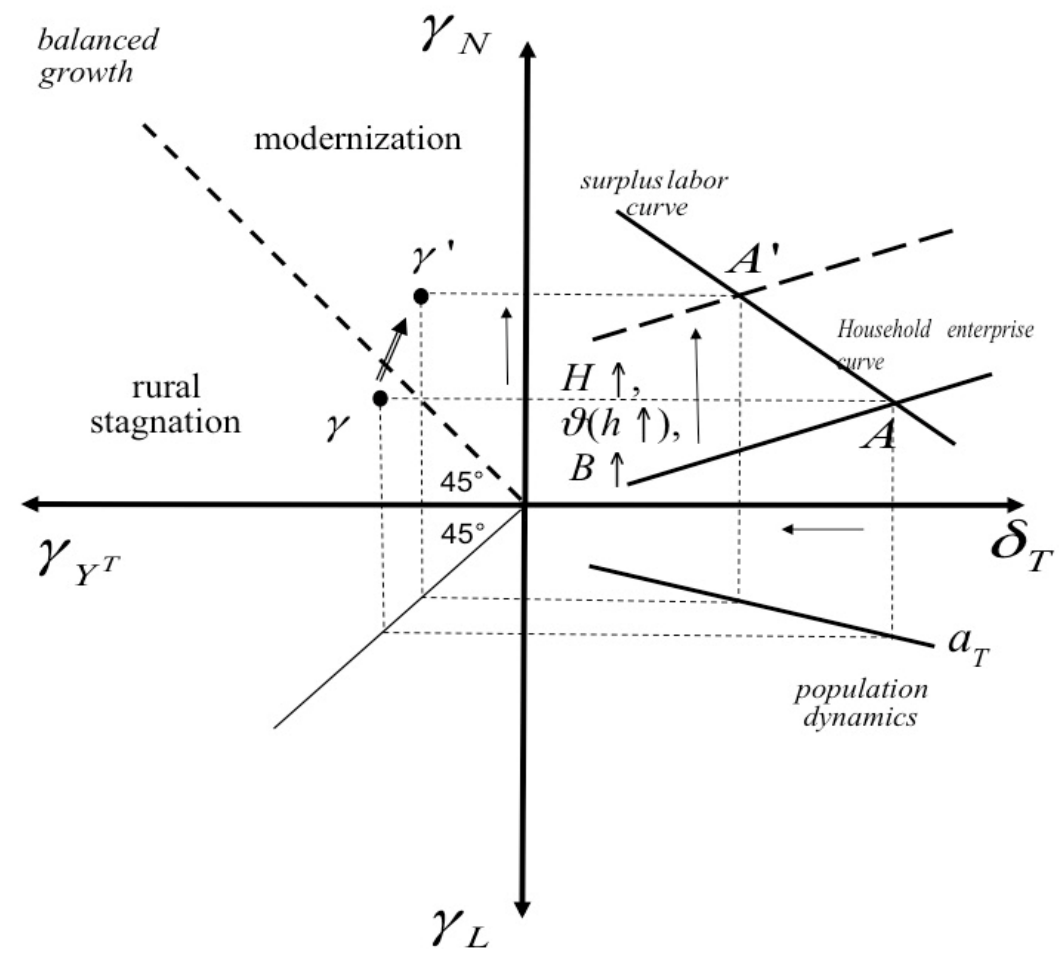

(Source: Based on Gries and Naudé, 2010)

Finally, for present purpose, although this is not formally derived here, the slope of the household enterprise curve will depend on the ease with which for a given population growth rate, surplus labour can migrate to the modern sector. One can show that if surplus labour move to a secondary city, it may be easier given 
proximity, ease of access to opportunities and other reasons (see section 4). Hence, by having more of such agglomerations, the slope of the household enterprise curve can become steeper and modernization can occur.

In Figure $8 \mathrm{I}$ show what can happen if it is easier to migrate, because there is a secondary city / rural agglomeration that can absorb farmers. The household enterprise curve swivels leading to the growth rate in household enterprises exceeding the growth rate in rural incomes, and the share of the modern sector relative to agriculture increasing.

Figure 8: Entrepreneurship and structural transformation: Secondary cities

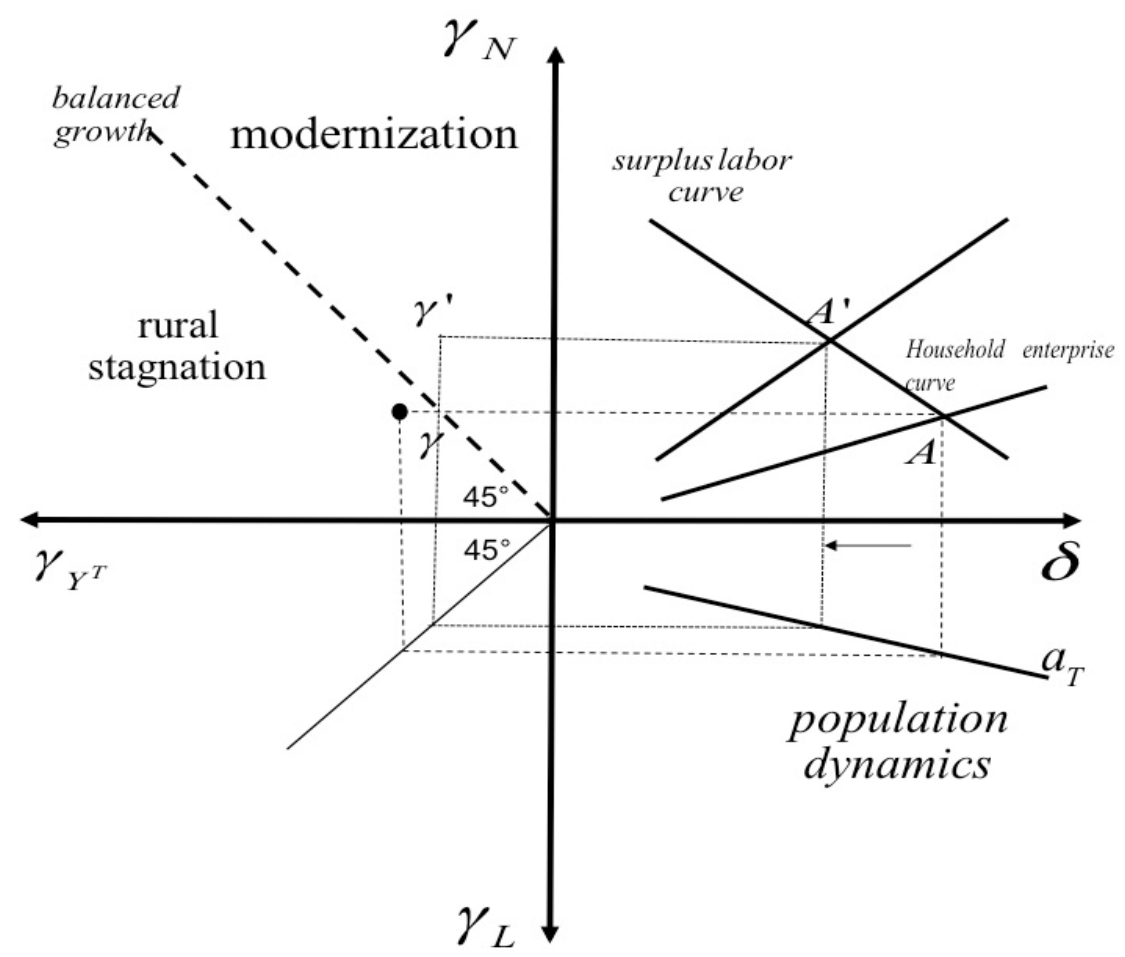

(Source: Based on Gries and Naudé, 2010)

In Figures 7 and 8 the structural transformation of the economy is driven by the entrepreneurship. Moreover, the service sector assumes an increasingly important role in the economy. This is consistent with the 'stylized facts' of structural change.

Although the productivity of household enterprises is constant in this model, total factor productivity in the final goods producing sector (manufacturing) increases the steeper the entrepreneurial start-up curve is, or the higher it shifts out. This is consistent with the observation that the manufacturing sector tends to be more productive than the services sector and agriculture.

In conclusion, in this simple model rural household enterprises can drive the process of re-allocation, structural transformation, and hence development. 


\section{Recent Empirical Evidence}

In the model described in section 3, some of the main implications were that (i) household enterprises and entrepreneurship can drive structural transformation by reallocating (surplus) farmers out of agriculture; (ii) entrepreneurship ability and other facilitating factors in start-ups and migration including finance and costs (business environment) will facilitate structural transformation and (iii) the proximity to secondary cities / rural agglomerations where a match between an opportunity and entrepreneurial ability is better, can facilitate structural transformation.

In this section I provide an overview of recent studies that found empirical evidence consistent with some of the above implications. This means that developing household enterprises and entrepreneurship in rural Africa, and promoting this in tandem with development of rural towns and secondary cities can have positive impacts on structural transformation.

\subsection{Household enterprises}

Household enterprises play perhaps a more important role in rural Africa than is appreciated. An earlier ' received wisdom' was that households in rural Africa was largely dependent on farming for income and was in fact more specialized in farming than rural households in other regions (e.g. Winters et al., 2009 and Davis et al., 2010). More recently however findings by Nagler and Naudé (2014) and Davis et al (2014) have found otherwise.

Nagler and Naudé (2014) using the LSMS-ISA ${ }^{12}$ dataset find that almost one-in-two (42 percent) of the 24,551 rural households surveyed in the LSMS-ISA operate a household enterprise. Income derived from such self-employment contributes between 9 percent in rural Malawi and 36 percent in rural Niger to average household income (Figure 9). Over time this share has shown a tendency to increase rather than decrease, as some development economists of the 1960s and 1970s had expected.

\footnotetext{
${ }^{12}$ The Living Standard Measurement Study - Integrated Surveys on Agriculture (LSMS-ISA) covered six African countries that were home to 51 percent of the population of Sub-Saharan African (SSA) in 2012. These six countries are Ethiopia, Malawi, Nigeria, Niger, Tanzania, and Uganda.
} 
Figure 9: Contribution to rural household income in African countries

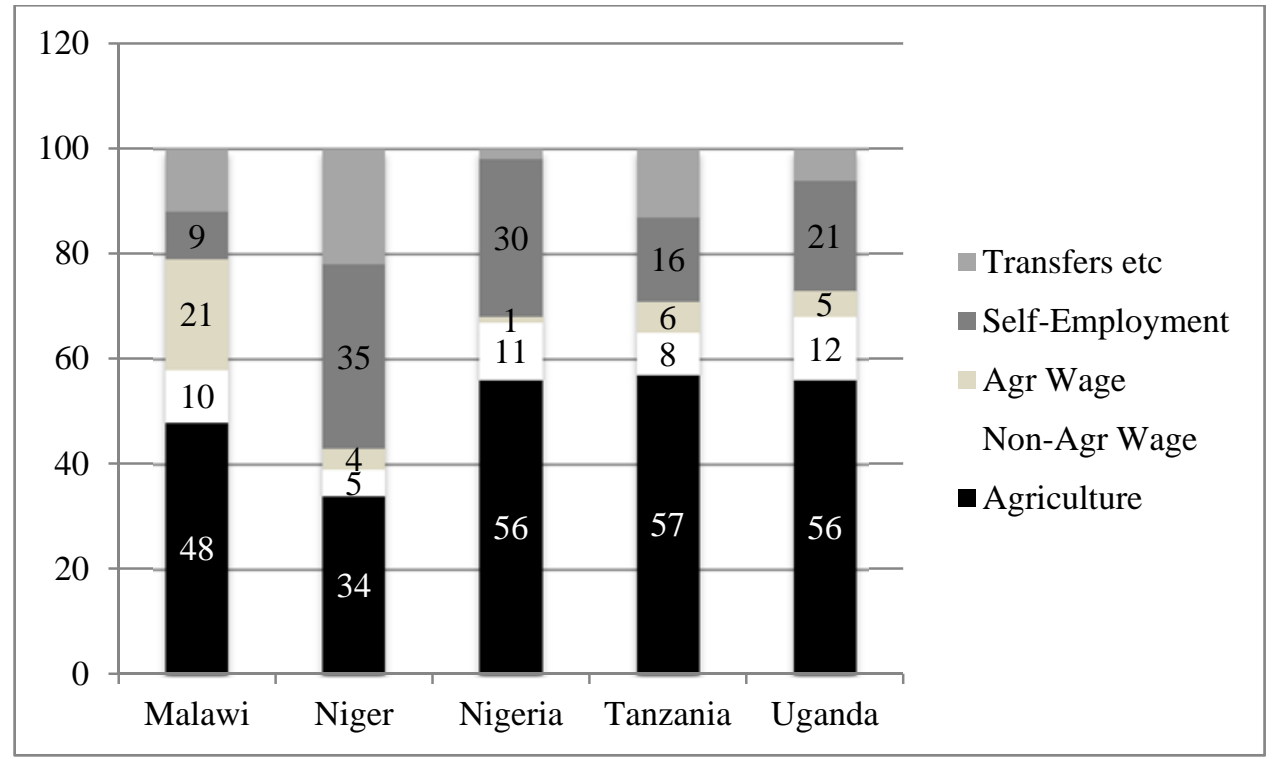

(Source: Nagler and Naudé, 2014)

Davis et al (2014) also using the more recent data from the LSMS-ISA data included in the RIGA data, finds that although African rural households do indeed tend to specialize more in agriculture than non-African households ${ }^{13}$, that there are more diversification in Africa than was thought. Moreover, they found that as GDP per capita in African countries increase, that this gives way 'to a greater reliance on nonfarm wage employment, with non-farm self-employment the activity of choice for a more or less constant share of households as development occurs...' (Ibid, p.15)

They also found that African rural households are much less dependent on transfer incomes, stating that 'interestingly, only one of the African countries in our sample has more than 5 percent of household specializing in transfer income (Kenya, with 9 percent). In non-African countries observing more than 5 percent of households receiving more than three quarters of their earnings form transfers is not at all uncommon'. As such they conclude that 'Despite the widespread migration and expanding social programs, productive occupations are what keep most households afloat' (Davis et al, 2014:15).

4.2 Rural entrepreneurship, entrepreneurial ability and household enterprise productivity

Entrepreneurial ability (and management practices) is as can be expected, important for rural entrepreneurship in Africa. It affects both start-up success as well as productivity. Until recently the received wisdom was that entrepreneurs in rural

13 'Once the level of GDP is controlled for the shares of income and participation in nonagricultural activities are not far-off from those found elsewhere' (Davis et al, 2014:28). 
Africa are largely so necessity and that uniformly characterise household enterprises by low-productivity.

Recently empirical evidence from Nagler and Naudé (2014) and McCullough has challenged this wisdom (2015). Nagler and Naudé (2014) present evidence that rural households do not only operate non-farm household enterprises due to necessity or survival, but also to exploit opportunities. They find that entrepreneurial skills (education) ${ }^{14}$, experience, wealth and access to credit, are significant determinants of a household's decision and ability to operate a non-farm enterprise.

Nagler and Naudé (2014) further find that many of these rural household enterprises are related to farming, such as enterprises providing inputs to or processing agricultural by-products, trading, and providing services. These three categories in total cover more that 50 per cent of household enterprises in Ethiopia, Malawi and Niger- see Figure 10.

Figure 10: Rural Non-Farm Activities: related to Farming?

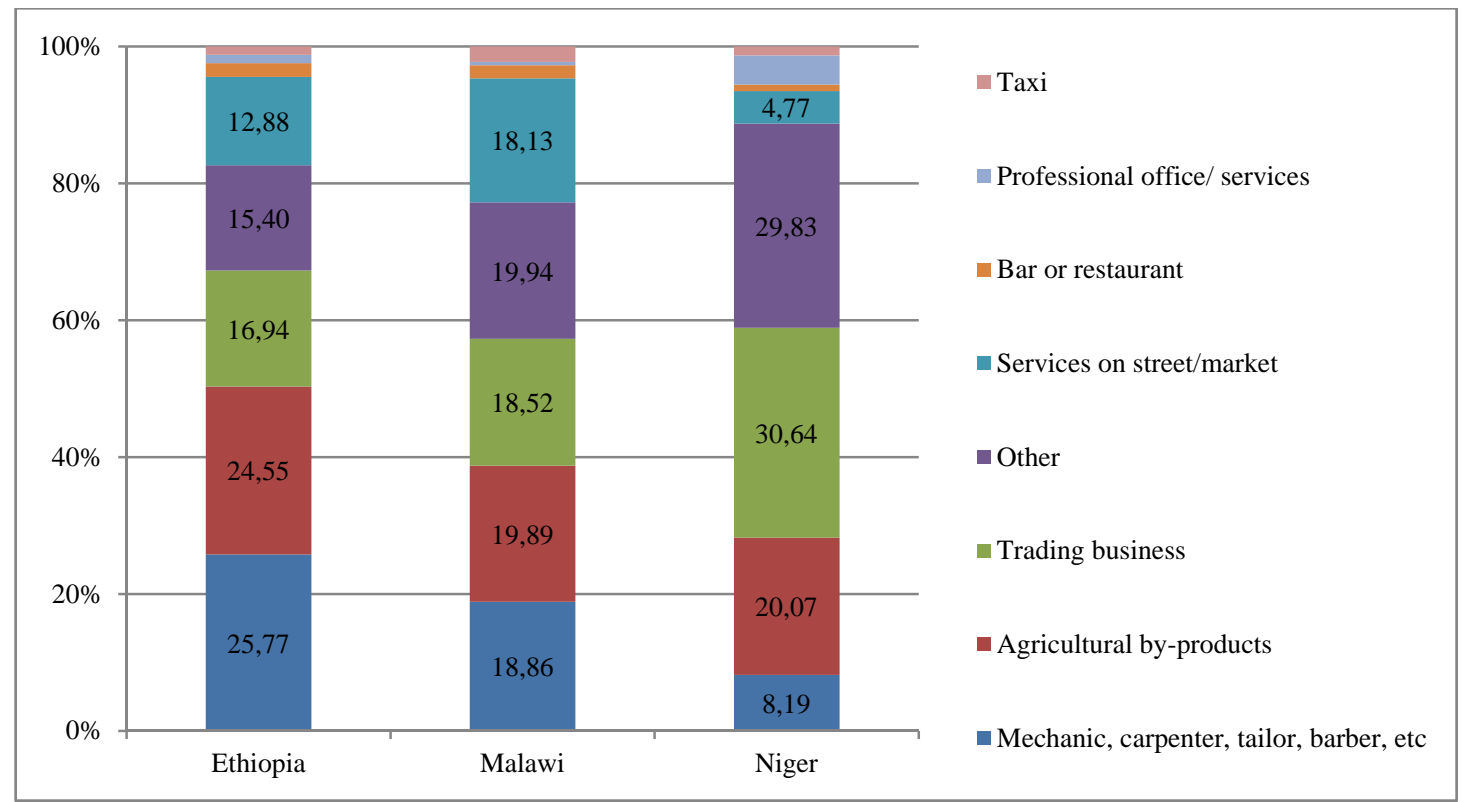

(Source: Nagler and Naudé, 2014)

They also compare labour productivity ${ }^{15}$ in rural household enterprises by their type of business and location, showing that entrepreneurial ability, business environment and distance to a secondary town or rural agglomeration matters. As far as entrepreneurial abilities and business environment is concerned they find that there is quite some heterogeneity amongst the productivity of labour in the different business

\footnotetext{
${ }^{14}$ In China, the re-allocation from rural farming to rural non-farming has been facilitated by education: households with better schooling were found in panel data studies to be more successful in diversifying into non-farm activities (Yang, 2004; Yang and An, 2002).

15 Nagler and Naudé (2014) measure enterprise productivity as labor productivity, measured as either average monthly sales, total sales during the last month of operation or average gross revenues, divided by the number of workers in the enterprise. They discuss many shortcomings in measuring the productivity of rural household enterprises.
} 
types as identified in Figure 10. Transport enterprises, bar and restaurants, professional services, non-agricultural business and trade are the more productivity types of businesses, while agribusinesses and the sales sector are less productive on average. This indicates that more 'difficult' to enter sectors, where entrepreneurial ability, experience and also capital create barriers to entry, are also more productive and lucrative.

As far as secondary towns (location) is concerned, using data from Uganda Nagler and Naudé (2014) find that household enterprises located within a $10 \mathrm{~km}$ radius from a secondary city to be the most productive, followed by household enterprises in a 25 to $50 \mathrm{~km}$ radius. If household enterprises are located more than $50 \mathrm{~km}$ away from a secondary city, they find significantly lower labour productivity.

Finally, McCullough (2015) provides a fresh perspective on the productivity gaps between African agriculture and non-agriculture, also using the micro-level LSMSISA survey data. It is worth quoting in full her conclusion that

\begin{abstract}
'Micro level cross-sector labor productivity gaps are smaller than those generated using national accounts data and vanish almost completely when computed on a perhour basis. The ratios of consumption levels per capita between households that primarily participate in agriculture vs. other sectors are also small, confirming small cross-sector gaps in returns to sector participation. Inter-sectoral differences in annual earnings per worker arise from differences in employment volume (hours per worker of labor supplied) rather than wages or productivity per hour of labor supplied. The tendency is for individuals participating in agriculture to supply fewer hours to agriculture, on average, than individuals participating in other sectors' (Ibid, p. 16).
\end{abstract}

The reason according to McCullough (2015) is that there is much underemployment in agriculture, with workers working fewer hours in agriculture than outside. This confirms the 'surplus labour' assumption from Lewis and also made in the underlying analysis of the model in section 3. Controlling for hours worked it seems that labour productivity in agriculture in Africa is perhaps higher than is commonly assumed. On a per-hour basis her estimate is that, labour may be only 1.6 times more productive in non-agriculture. This makes her beg the question 'Why don't agricultural workers work more hours per year?'

\title{
4.3 The (neglected) role of secondary cities
}

Until recently received wisdom held that structural transformation in Africa requires large-scale migration to mega-cities: mainly the so-called primary or capital cities. Most economic models of structural transformation indeed make a dichotomy only between rural areas and cities. More recent ideas and evidence have however started to question this simple dichotomy and suggests that rural towns and secondary cities have a much more important role to play in structural transformation of Africa than previous thought. Secondary cities in particular, dubbed part of the 'missing middle' being in between rural farms and mega-cities by Christiaensen and Todo (2014) can be a seedbed for entrepreneurship and household enterprises and hence facilitate the 
reallocation of African farmers.

Christiaensen and Todo (2014) found that labour migration from farms to the rural non-farm economy and to secondary towns generate more poverty reduction than labour migration to capital cities. They find that 'off-farm jobs generated in nearby villages or rural towns may be more readily accessible to the poor given lower thresholds to migrate and better compatibility with their skill set' (p.43).

Similar evidence comes from Christiaensen et al (2013). They found from a sample of 3301 individuals in rural Tanzania that between 1991 and 1994 around 50 per cent of people who escaped from poverty re-allocated out of agriculture- either into the rural non-farm economy or secondary towns.

In addition, using cross-country panel data over 1980 to 2004 covering 51 developing countries (with 14 in Africa) they find that a 1 per cent increase in the metropolitan share of the population leads to a 1.6 per cent increase in GDP per capita and that a 1 per cent increase in the share of the population in rural non-farm activities and secondary towns raises GDP per capita by 0.6 per cent. However, the increase in the latter is accompanied by significantly less inequality, leading the authors to conclude ${ }^{16}$ that 'migration out of agriculture into the rural economy and secondary towns is substantially more poverty reducing than metropolitization' (p.52).

Similarly, Beegle et al. (2011) using data from Tanzania covering 1991 to 2004 found that reallocating labour from agriculture into non-agriculture raised the welfare of migrant labourers and their households (as measured by consumption) but even more so of the individual who migrated to another geographical region. Specifically, they found that such out-migration could raise individual consumption by up to 36 per cent.

Secondary cities and emerging rural agglomerations provide seedbeds for entrepreneurs, including household enterprises to match opportunities and abilities better and hence improve the allocation of labour. Such agglomerations provide positive spillover effects through localization and urbanization externalities. Evidence of these in rural Africa comes from recent evidence by Owoo and Naudé (2014) using the geo-referenced LSMS-ISA dataset. They find that in Ethiopia there is spatial clustering of high and low productive production units - both of farms and non-farm household enterprises. This is because the productivity of a household enterprise or farm depends on the productivity of other enterprises or farms close-by (Mano et al., 2012:466). Productive enterprises therefore tend to cluster (Bloom et al., 2013; Martin et al., 2011; Ali and Peerlings, 2011; Nichter and Goldmark, 2009; Foster et al., 2008).

\footnotetext{
16 As Christiaensen et al. (2013) argue, productivity might be higher in metropolitan areas, but not all inhabitants from rural areas are or will be able to access opportunities in these areas. They find that only one in seven people who escaped from poverty did so through migrating to a large city, but that one in two did so by moving to secondary towns.
} 
Owoo and Naudé (2014) measure the productivity of rural non-farm household enterprises as output (sales) per labour (in Ethiopian Birr and Nigerian Naira) and produced quintile maps to depict the distribution of enterprise productivity across space in both countries. They show that rural non-farm household enterprise productivity is highly clustered in Ethiopia and Nigeria. It is highest around Tigray, Amhara, Somali and Oromia regions of Ethiopia; and in the south of Nigeria. Owoo and Naudé (2014) also note that there are many high-productivity 'hubs' outside the capital cities in rural areas.

Given the large rural areas in Africa and the benefits from clustering/ agglomeration in secondary cities, it is very likely as Siba et al. (2012:2) point out that '...spillovers and other externalities may have large effects on firm performance in this environment, since most firms operate far away from the best practice frontier, implying considerable scope for learning'. Similarly Rijkers et al. (2010:1291) argue that '...even limited interaction is likely to lead to substantial increases in efficiency'.

The reallocation of economic activity into secondary cities and towns in Africa will thus likely have significant productivity benefits.

\section{Concluding Remarks}

Africa remains the poorest continent. As Young (2012: 733) importantly stressed, 'Africa is much poorer than other developing countries, with levels of log consumption 98 percent lower than those enjoyed by the other developing countries'.

Africa needs to structurally transform to raise labour productivity and to enable both its agriculture and manufacturing sectors to benefit from the substantial opportunities that currently exist in the global economy. First there is a favourable global market for its agrifood industry. Second there is the potential to develop its manufacturing industry in the wake of rising labour costs in China and country's manufacturing industries gradually decreasing its demand for low-skilled labour and introducing machines and automation (Brynjolfsson and McAfee, 2011; Chandy et al., 2012:34).

So far African countries have failed to make the structural transformation and utilise these opportunities in full. Labour productivity has remained relatively low and widely dispersed between sectors and within-sectors.

In this paper I argued that Africa's farmers therefore needs to be reallocated out of farming, and into non-farm sectors, including household enterprises. Furthermore, they also need to be reallocated across space, to cities and moreover to secondary cities and towns. Given the large productivity gaps noted between sectors and between urban and non-urban settings, the reallocation of Africa's farmers can result in sizeable productivity and growth gains.

How to do so remains the question. From the contribution of this paper one answer is that entrepreneurs, reacting to opportunities in the modern sectors, and in particular secondary towns and cities and rural dense areas, can through creation of household 
enterprises contribute to modernization. But they need support in terms of their capacity and abilities, credit and finance, business environment and infrastructure, and support for migration to cities.

The policies and strategies to achieve this may necessitate overcoming a number of structural or institutional weaknesses and constraints in Africa. One is, as Collier and Dercon (2014) has argued of getting more broad acceptance of the need for strategies that does not only focus on promoting smallholder agriculture, but are more 'radical' including promotion of large scale, commercial farming and the facilitation of migration from rural areas to (secondary) cities. A second is to reduce the occupational mismatches (labour market failures) that result in keeping people in farming that could be more productive elsewhere. In this respect two issues need to be considered.

The first is that a significant gap exists in the provision inadequate social protection and insurance mechanisms in Africa. These can, given the risks of doing business in Africa, and the risks that rural households (still the majority of the population in most African countries) face, have significant efficiency effects in supporting more risktaking and more effective allocation of resources towards the kind of highproductivity household enterprises that are needed (Nagler and Naudé, 2014).

The second is that irresponsible state intervention in reallocation of farmers often does more harm than good. Here land reform and 'land grabbing' processes are increasingly gathering concern. As Jayne and Anriquez (2013:16) warn 'case studies show that typically only a small proportion of the land acquired through these state processes is productively utilized and that land speculation and "bonanza farms" are common. ... These processes, if continued, will impede the rate of growth at which new land is put into production until land markets develop to put more land into the hands of those with the skills to farm it productively'. Land reform thus most often exacerbates the occupational mismatches that were shown in this paper to reduce labour productivity in African farming.

A final conclusion is more of a warning. Despite the wide consensus about Africa's patterns and failures in terms of structural transformation and productivity, there is much that is actually quite subject to uncertainty, due to the poor overall quality of data in Africa (see e.g. Jerven and Johnston, 2015). Devarajan (2013) has described this as Africa's 'Statistical Tragedy'. It is especially in agriculture that the difficulties are acute (see Carletto et al., 2015). As Christiaensen (2015) notes,

'When it comes to agriculture, the problems only multiply with maize yield estimates, for example, varying substantially depending on the data source (by about 1 ton per ha between 1.7 and 2.6 ton/ha in Malawi in 2006/7...Are we flying blind or vision impaired?'

Because of poor agricultural data, the World Bank started in 2013 the project 'African 
Agriculture: Telling Myths from Facts ${ }^{17}$ to evaluate a set of received wisdoms about African agriculture, and to attempt to remove the dust that has settled on these, using relative recent improvements in data from the LSMS-ISA surveys. The project identified no less that 15 such potential myths (see Christiaensen, 2015). While perhaps not all these potential myths are real myths, and many may be confirmed as facts, results to date have already underscored the importance of being more critical about the received wisdoms regarding African agriculture. One wisdom though that it does confirm is that the best way to develop Africa's agriculture is to reallocate substantial numbers of its farmers to other sectors and locations.

\section{Acknowledgements}

I am grateful to Professor Johann Kirstein for useful suggestions on an earlier draft. I am also grateful for comments from various participants at the $53^{\text {rd }}$ Annual Conference of the Agricultural Economics Association of South Africa held between 29 September and 2 October 2015 in the Vredefort Dome in the North West Province. Last but not least I appreciate the opportunity to have discuss the concept of this lecture and related agricultural economic matters with Dr. Ernst Idsardi.

\footnotetext{
${ }^{17}$ See http://www.worldbank.org/en/programs/africa-myths-and-facts
} 


\section{References}

Acemoglu, D. and Robinson, J.A. (2011). 'Why is Africa Poor?' Economic History of Developing Regions, 25 (1): 21-50.

Adamopoulos, T. (2011). 'Transportation Costs, Agricultural Productivity and CrossCountry Income Differences', International Economic Review, 52(2): 489-500.

Alene, D.A. (2010). 'Productivity Growth and the Effects of R\&D in African Agriculture', Agricultural Economics, 41(3-4): 223-238.

Ali, M. and Peerlings, J. (2011). 'Value Added of Cluster Membership for Micro Enterprises of the Handloom Sector in Ethiopia', World Development, 39 (3): 363374.

Arnold, J., Mattoo, A., and Narciso, G. (2006). 'Services Inputs and Firm Productivity in Sub-Saharan Africa: Evidence from Firm-Level Data, World Bank Policy Research Working Paper No. 4048. Washington DC: The World Bank.

Bartelsman, E., Haltiwanger, J. and Scarpetta, S. (2013). 'Cross-Country Differences in Productivity: The Role of Allocation and Selection', American Economic Review, 103 (1): 305-334.

Beegle, K., De Weerdt, J. and Dercon, S. (2011). 'Migration and Economic Mobility in Tanzania: Evidence from a Tracking Survey', Review of Economics and Statistics 93 (August): 1010-1033.

Binswanger-Mkhize, H. P., A. F. McCalla, and P. Patel. (2010). 'Structural Transformation and African Agriculture', Global Journal of Emerging Market Economies 2: 113-52.

Bloom, N., and Van Reenen, J. (2010). 'Why do Management Practices Differ Across Firms and Countries?’ Journal of Economic Perspectives, 24 (1): 203-224.

Bloom, N., Schankerman, M. and Van Reenen, J. (2013). 'Identifying Technology Spillovers and Product Market Rivalry’, Econometrica, 81 (4): 1347-1393.

Bonnet, J., Cieply, S. and Dejardin, M. (2005). 'Financial constraints on new firms: Looking for regional disparities', Discussion paper no 3705, Max Planck Institute of Economics, Jena.

Bosker, M. and Garretsen, H. (2012). 'Economic Geography and Economic Development in Sub-Saharan Africa', World Bank Economic Review, 26(3): 443-485.

Brynjolfsson, E. and McAfee, A. (2011). 'Why Workers are Losing the War Against Machines', The Atlantic, 26 October. Online at http://www.theatlantic.com/business/archive/2011/10/why-workers-are-losing-thewar-against-machines/247278/

Carletto, C., Jolliffe, D. and Banerjee, R. (2015). 'From Tragedy to Renaissance: Improving Agricultural Data for Better Policies’, Journal of Development Studies, 51 (2): 133-148. 
Caselli, F., and Coleman II, J.W., (2001). 'The US structural transformation and regional convergence: a reinterpretation', Journal of Political Economy 109 (3): 584616.

Chandy, L., Dervis, K. and Rocker, S. (2012). 'Clicks into Bricks, Technology into Transformation, and the Fight against Poverty', Brookings Blum Roundtable 2012. The Brookings Institute.

Christiaensen, L. and Kaminski, J. (2014). Unpublished draft paper.

Christiaensen, L. (2015). 'Agriculture in Africa- Telling Facts from Myths', Published on Africa Can End Poverty Blog (http://blogs.worldbank.org/africacan/agriculture-in-africa-telling-facts-from-myths).

Christiaensen, L. and Chuhan-Pole, P. (2015) 'Growth, Structural Transformation and Poverty Reduction in Africa', Presentation at the World Bank Africa Office, Brussels, 9 January.

Christiaensen, L. and Naudé, W. (2015). 'Secondary “Cities”, Poverty Reduction and the Transformation of Agrifood Systems in Africa', Paper presented at the Rapid Agrifood System Transformation, Globalization, and International Development at the Preconference of AAEA Meetings, San Francisco, USA, 25 July 2015.

Christiaensen, L. and Todo, Y. (2014). 'Poverty Reduction During the Rural-Urban Transformation - the role of the Missing Middle', World Development, 63: 43-58.

Christiaensen, L., Demery, L. and Kuhl, J. (2011). 'The (Evolving) Role of Agriculture in Poverty Reduction - an Empirical Perspective', Journal of Development Economics, 96(2): 239-254.

Christiaensen, L., Kilic, T. and Palacios-Lopez, A. (2015). 'Killing the Zombie Statistic: Women Contribute 60-80 per cent of Labour in African Agriculture', Published on Africa Can End Poverty, (http://blogs.worldbank.org/africacan/killingthe-zombie-statistic-women-contribute-60-80-percent-of-labor-in-africanagriculture).

Ciccone, A. and Matsuyama, K. (1996). 'Start-up Costs and Pecuniary Externalities as Barriers to Economic Development', Journal of Development Economics, 4: 33-59.

Collier, P. and Dercon, S. (2014). 'African Agriculture in 50 Years: Smallholders in a Rapidly Changing World?’ World Development, 63 (4): 92-101.

Collier, P. and Gunning, J.W. (1999). 'Explaining African Economic Performance', Journal of Economic Literature, 37: 64-111.

Culey, S. (2012). 'Transformers: Supply Chain 3.0 and How Automation Will Transform the Rules of the Global Supply Chain', The European Business Review, Nov.

Davis, B., Di Giuseppe, S. and Zezza, A. (2014). Income Diversification Patterns in Rural Sub-Saharan Africa Reassessing the Evidence, Policy Research Working Paper 7108, Washington DC: The World Bank. 
Davis, B., P. Winters, G. Carletto, K. Covarrubias, E. Quinones, A. Zezza, K. Stamoulis, G. Bonomi, and S. Di Giuseppe. (2010). 'Assets, Activities and Rural Poverty Alleviation: Evidence from a Multicountry Analysis’, World Development, 38 (1): 48-63.

De Brauw, A., Mueller, V. and Lee, H.L. (2014). 'The Role of Rural-Urban Migration in the Structural Transformation of Sub-Saharan Africa', World Development, 62:3342.

De Vries, G., Timmer, M. and De Vries, K. (2013). 'Structural Transformation in Africa: Static Gains, Dynamic Losses', GGDC Research Memorandum 136. University of Groningen.

Deichmann, U., Shilpi, F., and Vakis, R. (2008). 'Spatial Specialization and FarmNonfarm Linkages', World Bank Policy Research Working Paper no. 4611. Washington DC: The World Bank.

Dethier, J., Hirn, M., and Straub, S. (2010). 'Explaining Enterprise Performance in Developing Countries with Business Climate Survey Data', World Bank Research Observer, 26:258-309.

Devarajan, S. (2013). 'Africa's Statistical Tragedy', Review of Income and Wealth, 59 (S1): S9-S15.

Dollar, D., Hallword-Driemeier, M., and Mengistae, T. (2005). 'Investment Climate and Firm Performance in Developing Countries', Economic Development and Cultural Change, 54 (1): 1-31.

Dorosh, P. and Thurlow, J. (2014). 'Can Cities or Towns Drive African Development? Economy-wide analysis for Ethiopia and Uganda', World Development, 63:113-123.

Easterly, W., and R. Levine (2003). 'Tropics, Germs, and Crops: The Role of Endowments in Economic Development', Journal of Monetary Economics, 50 (1): 339.

Eifert, B., Gelb, A., and Ramachandran, V. (2008). 'The Cost of Doing Business in Africa: Evidence from Enterprise Survey Data', World Development, 36 (9):15311546.

Foster, L., Haltiwanger, J. and Syverson, C. (2008). 'Reallocation, Firm Turnover and Efficiency: Selection on Productivity or Profitability', American Economic Review, 98 (1): 394-425.

Fox, L., Haines, C., Munoz, J. and Thomas, A. (2013). 'Africa's Got Work to Do: Employment Prospects in the New Century', IMF Working Paper no WP/13/201.

Fulginiti, L. E., Perrin R. K., and Yu, B. (2004). 'Institutions and agricultural productivity in Sub-Saharan Africa', Agricultural Economics, 31: 169-180. 
Fuglie, K.O. (2010). 'Total Factor Productivity in the Global Agricultural Economy: Evidence from FAO Data' (In The Shifting Patterns of Agricultural Production and Productivity Worldwide. Midwest Agribusiness Trade Research and Information Center, Iowa State University. Chapter 4).

Gennaioli, N. and Rainer, I. (2007). 'The Modern Impact of Precolonial Centralization in Africa', Journal of Economic Growth, 12: 185-234.

Gollin, D., Lagakos, D. and Waugh, M.E. (2014). 'The Agricultural Productivity Gap’, Quarterly Journal of Economics, 129 (2): 939-993.

Gollin, D., Parente, S.L. and Rogerson, R. (2004). 'Farm Work, Home Work and International Productivity Differences', Review of Economic Dynamics, 7: 827-850.

Gollin, D., Parente, S.L. and Rogerson, R. (2002) 'The Role of Agriculture in Development', American Economic Review Papers and Proceedings, 92 (2): 160 164.

Gries, T. and Naudé, W. (2010). 'Entrepreneurship and Structural Economic Transformation’, Small Business Economics Journal, 34 (1): 13-29.

Haggblade, S. (2013). ‘Agriculture and Africa’s Structural Transformation', Paper presented at the Wilson Center and USAID Alumni Association, Michigan State University, 22 May.

Hall, R. and Jones, C. (1999). 'Why do Some Countries produce so Much More Output per Worker than others?’ Quarterly Journal of Economics, 114(1): 83-116.

Harrison, A.E., Lin, J.Y. and Xu, L.C. (2014). 'Explaining Africa’s (Dis) Advantage', World Development, 63: 59-77.

Headey, D.D. and Jayne, T.S. (2014), 'Adaptation to Land Constraints: Is Africa Different', Food Policy, 48: 18-33.

Hsieh, C. and Klenow, P. J. (2009). 'Misallocation and Manufacturing TFP in China and India', Quarterly Journal of Economics, 124 (4): 1403-1448.

Hummels, D. (1999). 'Have International Transportation Costs Declined?’. Available at: www.nber.org/ confer/99/itisi99/hummels.pdf.

Jayne, T.S. and Anriquez, G. (2013). 'African Agriculture Toward 2030: Changes in Urbanisation and Agricultural Land Dynamics and their Implications for CGIAR research', Paper prepared for the ISPC Foresight Meeting, January 24-25, Boston.

Jerven, M. (2010). 'African Growth Recurring: An Economic History Perspective on African Growth Episodes, 1690-2010', Economic History of Developing Regions, 25(2): 127-154.

Jerven, M. and Johnston, D. (2015). 'Statistical Tragedy in Africa? Evaluating the Data Base for African Economic Development', Journal of Development Studies, 51 (2): 111-115. 
Kariuki, J.G. (2011). The Future of Agriculture in Africa, The Pardee Papers no 15, Aug.

Kirsten, J. and Liebenberg, F. (2015). 'Transforming African Economies and the Evolving Structure of African Agriculture', Draft Paper, University of Pretoria, 15 July.

Lagakos, D. and Waugh, M.E. (2013). 'Selection, Agriculture, and Cross-Country Productivity Differences’, American Economic Review, 103 (2): 948-980.

Lele, U., Agarwal, M., Timmer, P. and Goswami, S. (2015). 'Patterns of Structural Transformation and Agricultural Productivity Growth with Special Focus on Brazil, China, Indonesia and India', Paper presented at the Conference on Policy Options and Investment Priorities for Agricultural Productivity Growth, New Dehli, $9-11$ November.

Liebenberg, F. (2013). South African Agricultural Production, Productivity and Research Performance in the $20^{\text {th }}$ Century. University of Pretoria. PhD Thesis,

Lin, J.Y. and Yu, M. (2015). 'Industrial Upgrading and Poverty Reduction in China' (In Naudé, W., Szirmai, A. and Haraguchi, N. eds. Structural Change and Industrial Development in the BRICS. Oxford: Oxford University Press. Pp.93-118).

Mano, Y., Iddrisu, A., Yoshino, Y. and Sonobe, T. (2012). 'How can Micro and Small Enterprises in Sub-Saharan Africa Become More Productive? The Impacts of Experimental Basic Managerial Training', World Development, 40 (3): 458-468.

Martin, P., Mayer, J. and Mayneris, F. (2011). 'Spatial Concentration and Plant-Level Productivity in France’, Journal of Urban Economics, 69: 182-195.

McCullough, E.B. (2015). 'Labor Productivity and Employment Gaps in Sub-Saharan Africa’ Policy Research Working Paper 7234, Washington DC: The World Bank.

McKenzie, D. and Woodruff, C. (2015). 'Business Practices in Small Firms in Developing Countries', NBER Working Paper no. 21505. National Bureau for Economic Research.

McMillan, M, and Rodrik, D. (2011). 'Globalization, Structural Change and Productivity Growth', National Bureau of Economic Research Working Paper Series No. 17143.

McMillan, M. and Harttgen, K. (2014). 'What Is Driving the African Growth Miracle?’ National Bureau of Economic Research Working Paper Series No. 20077.

McMillan, M., and Headey, D. (2014). 'Introduction - Understanding Structural Transformation in Africa’, World Development 63: 1-10.

Miguel, E. and Hamory, J. (2009). 'Individual Ability and Selection into Migration in Kenya’, UNDP Human Development Research Paper 2009/45.

Nagler, P. and Naudé, W. (2014). 'Non-farm enterprises in rural Africa: new empirical evidence’, Policy Research Working Paper no. 7066. Washington DC: The 
World Bank.

Naudé, W. (2009). 'Geography, transport and Africa’s proximity gap', Journal of Transport Geography, 17 (1): 1-9.

Naudé, W. (2011). 'Entrepreneurship is not a Binding Constraint on Growth and Development in the Poorest Countries', World Development, 39 (1): 33-44.

Naudé, W. and Matthee, M (2007). 'The Significance of Transport Costs in Africa'. United Nations University Policy Brief 6. Tokyo: UNU.

Ndulu, B., R. Bates, P. Collier, and S. O’Connell (2007). The Political Economy of African Economic Growth 1960-2000. Cambridge: Cambridge University Press.

Nichter, S. and Goldmark, L. (2009). 'Small Firm Growth in Developing Countries', World Development, 37 (9): 1435-1464.

Nunn, N. and Puga, D. (2012). 'Ruggedness: The Blessing of Bad Geography in Africa', Review of Economics and Statistics, 94: 20-36.

Owoo, N. and Naudé, W. (2014). 'Non-Farm Enterprise Productivity and Spatial Autocorrelation in Rural Africa: Evidence from Ethiopia and Nigeria', IZA Discussion Paper no. 8295. Bonn: Institute for the Study of Labour.

Palacios-Lopez, A., Christiaensen, L. and Kilic, T. (2015). 'How much of the Labor in African Agriculture is provided by Women?', Policy Research Working Paper 7282. Washington DC: The World Bank.

Rabobank (2013). The Future of Farming: The Rise of the Rural Entrepreneur.

Restuccia, D. and Rogerson, R. (2013). 'Misallocation and Productivity', Review of Economic Dynamics, 16 (1): 1-10.

Rijkers, B., Soderbom, M., and Loening, J.L. (2010). 'A Rural-Urban Comparison of Manufacturing Enterprise Performance in Ethiopia', World Development, 38 (9): 1278-1296.

Rodrik, D. (2014). 'An African Growth Miracle?’ NBER Working Paper no. 20188. National Bureau of Economic Research.

Sachs, J. D., J. W. McArthur, G. Schmidt-Traub, M. Kruk, C. Bahadur, M. Faye, and G. McCord (2004). 'Ending Africa's Poverty Trap'. Brookings Papers on Economic Activity, 1: 117-216.

Schultz, T.W. (1953). The Economic Organization of Agriculture. New York: McGraw Hill.

Siba, E., Söderbom, M., Bigsten, A., and Gebreeyesus, M. (2012). 'Enterprise Agglomeration, Output Prices and Physical Productivity: Firm-Level Evidence from Ethiopia', UNU-WIDER Research Paper WP2012/85. 
Söderbom, M. and Teal, F. (2004). Size and efficiency in African manufacturing firms: evidence from firm-level panel data', Journal of Development Economics, 73(1): 369-394.

Stiglitz, J. and Weiss, A. (1992). 'Asymmetric Information in Credit Markets and its Implications for Macro-economics’, Oxford Economic Papers, 44(4): 694-724.

Syverson, C. (2011). 'What Determines Productivity?' Journal of Economic Literature, 49 (2): 326-365.

Van Biesebroeck, J. (2005). 'Exporting Raises Productivity in Sub-Saharan Manufacturing Firms', Journal of International Economics, 67 (2): 373-391.

Vollrath, D. (2009). 'How Important Are Dual Economy Effects for Aggregate Productivity?' Journal of Development Economics, 88: 325-334.

Vollrath, D. (2009). 'How Important Are Dual Economy Effects for Aggregate Productivity?' Journal of Development Economics, 88: 325-334.

Williams, D. (2007). 'Gone to Seed’. Financial Mail, 20 July: 70-1.

Winters, P., B. Davis, G. Carletto, K. Covarrubias, E. Quinones, A. Zezza, K. Stamoulis, G. Bonomi, and S. DiGiuseppe. (2009). 'A Cross Country Comparison of Rural Income Generating Activities’, World Development, 37(9): 1435-1452.

Yang, D.T. (2004). 'Education and Allocative Efficiency: Household Income Growth During Rural Reforms in China’, Journal of Development Economics, 74: 137-162.

Yang, D.T. and An, M.Y. (2002). 'Human Capital, Entrepreneurship, and Farm Household Earnings', Journal of Development Economics, 68: 65-88.

Young, A. (2012). 'The African Growth Miracle', Journal of Political Economy, 120: 696-739.

Zhang, J. (2002). 'Urbanization, Population Transition, and Growth'. Oxford Economic Papers, 54: 91-117. 